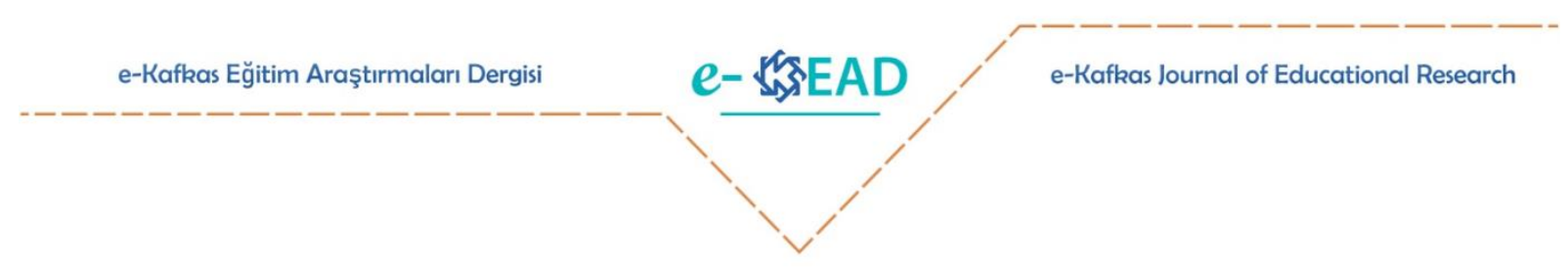

\title{
Examining of Perception Levels of Secondary Education Students Regarding Outdoor Learning
}

\section{Pınar Tağrikulu1 ${ }^{1}$ Ayça Cirit Gül ${ }^{2} \quad$ Elif Omca Çobanoğlu ${ }^{3}$}

\section{To cite this article:}

Tağrikulu, P., Cirit Gül, A. \& Çobanoğlu, E. O. (2021). Examining of perception levels of secondary education students regarding outdoor learning. e- Kafkas Journal of Educational Research, 8, 499513. doi:10.30900/kafkasegt.953811

\section{Research article}

Received: 17.06 .2021

Accepted:02.11.2021

\begin{abstract}
The many positive effects of outdoor learning on students form a good idea about the necessity of maintaining this model with students. However, at this point, perhaps the most important detail to be considered is the level of perception of the students who are directly involved in the subject of outdoor learning. This study is a quantitative study conducted to determine the perception levels of secondary school students towards outdoor learning. The study was designed in accordance with the survey model. 980 participants were included in the study on a voluntary basis. The study data were collected through the "Out of School Learning Environments Perception Scale (OSLEPS)". The items in this scale were collected using an online form. In the analysis of the data, t-test for independent samples and one-way analysis of variance for independent samples were used. In this study, which was conducted to determine the perceptions of students about outdoor learning environments, the answers given by the students participating in the study to the OSLEPS were evaluated in terms of their gender, grade level, living place and where they spend their holidays. As a result of the analyzes, both female and male students have higher perceptions of willingness to learn and integration with other courses, that outdoor learning environments have a greater effect on female students than male students and female students' perceptions of outdoor learning environments are higher than male students. When the studies in the literature and this study are evaluated together, it is seen that the results obtained overlap with each other. When evaluated in terms of other factors, no significant difference was found between the variables. Since outdoor education activities are an educational process in which the five senses are used together, there are activities in which movement, excitement and curiosity are involved, it ensures that students are constantly active in the process, increases their desire for learning and presents information from different disciplines as a whole, it can be suggested that such activities should be included more in the curriculum prepared.
\end{abstract}

Key Words: Outdoor education, outdoor learning, out of school learning environments perception scale, secondary education school

\footnotetext{
1(D) Corresponding Author, Research Assistant, Ondokuz Mayıs University, Faculty of Education, Turkey.

2 (i) Research Assistant, Ondokuz Mayıs University, Faculty of Education, Turkey.

3 (iD) Associate Professor, Ondokuz Mayıs University, Faculty of Education, Turkey.
} 


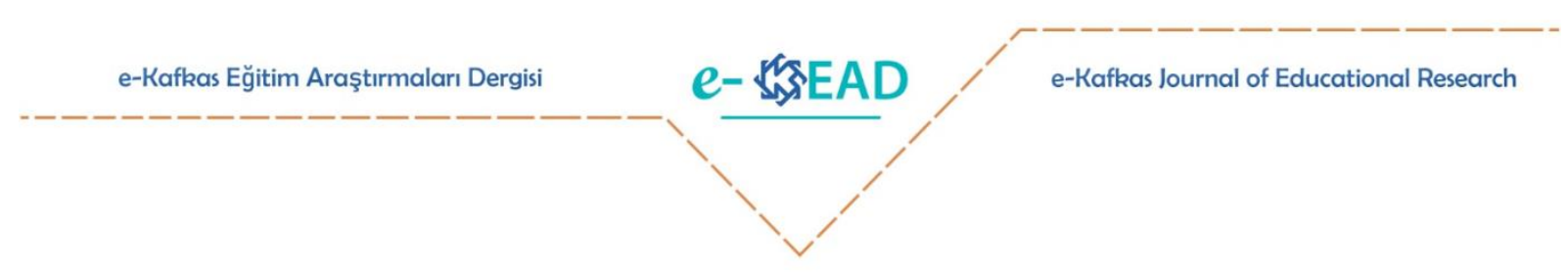

\title{
Ortaokul Öğrencilerinin Okul Dışı Öğrenmeye Yönelik Algı Düzeylerinin İncelenmesi Pınar Tağrikulu ${ }^{1} \quad$ Ayça Cirit Gül ${ }^{2} \quad$ Elif Omca Çobanoğlu ${ }^{3}$
}

\author{
Atıf: \\ Tağrikulu, P., Cirit Gül, A. ve Çobanoğlu, E. O. (2021). Ortaokul öğrencilerinin okul dış1 öğrenmeye \\ yönelik alg1 düzeylerinin incelenmesi. e- Kafkas Ĕ̈itim Araştırmaları Dergisi, 8, 499-513. \\ doi:10.30900/kafkasegt.953811
}

Araştırma Makalesi

Geliş Tarihi:17.06.2021
Kabul Tarihi: 02.11.2021

\section{$\ddot{\mathbf{O z}}$}

Okul dışı öğrenmenin öğrenciler üzerinde ortaya çıkardığı pek çok olumlu etki bu modelin öğrenciler ile sürdürülmesi gerekliliği hakkında iyi bir fikir oluşturmaktadır. Ancak bu noktada göz önünde bulundurulması gereken belki de en önemli detay, okul dışı öğrenme konusunun doğrudan muhatabı olan öğrencilerin konu hakkındaki algılarının ne düzeyde olduğudur. Bu çalışma, ortaokul kademesinde öğrenim gören öğrencilerin okul dışı öğrenmeye yönelik algı düzeylerinin belirlenmesi amacıyla yapılan nicel bir çalışmadır. Çalışma tarama modeline uygun olarak tasarlanmıştır. Çalışmaya gönüllülük esasına dayalı olarak 980 katılımcı dâhil edilmiştir. Çalışma verileri "Okul Dışı Öğrenme Ortamları Algı Ölçeği (ODOAL)" aracılığıyla toplanmıştır. Söz konusu ölçekte yer alan maddeler çevrimiçi bir form kullanılarak toplanmıştır. Verilerin analizinde bağımsız örneklemler için t-testi ve bağımsız örneklemler için tek yönlü varyans analizi teknikleri kullanılmıştır. Öğrencilerin okul dışı öğrenme ortamlarına ilişkin algılarının belirlenmesi amacıyla yapılan bu çalışmada, çalışmaya katılan öğrencilerin ODOAL'a verdikleri yanıtlar, cinsiyetleri, öğrenim gördükleri sınıf düzeyleri, yaşadıkları yerler ve tatillerini geçirdikleri alanlar boyutlarında değerlendirilmiştir. Yapılan analizler sonucunda hem kı hem de erkek öğrencilerde öğrenmeye yönelik isteklilik ve diğer derslerle bütünleştirme boyutlarında algılarının yüksek olduğu, okul dışı öğrenme ortamlarının kız öğrencilerde erkek öğrencilere göre daha fazla etkisinin olduğu ve okul dışı öğrenme ortamlarına ilişkin algılarına göre de kız öğrencilerin algılarının erkek öğrencilerden daha yüksek olduğu sonucuna ulaşılmıştır. Literatürdeki çalışmalar ile bu çalı̧̧ma bir arada değerlendirildiğinde de elde edilen sonuçların birbiri ile örtüştüğü görülmektedir. Diğer faktörler açısından değerlendirildiğinde ise değişkenler arasında anlamlı bir farklılık bulunamamıştır. Okul dışı eğitim etkinlikleri beş duyu organının bir arada kullanıldığ 1 , içinde hareket, heyecan ve merakın bulunduğu etkinliklerin olduğu, öğrencilerin süreç içinde sürekli aktif olmasını sağlayan ve öğrenmeye yönelik isteklerini artıran, farklı disiplinlere ait bilgileri bir bütün halinde sunan bir eğitim süreci olduğundan dolayı hazırlanan öğretim programlarında bu tür etkinliklere daha fazla yer verilmesi önerilebilir.

Anahtar Sözcükler: Okul dışı eğitim, okul dış1 öğrenme, okul dış1 öğrenme ortamları alg1 ölçeği, ortaokul öğrencileri

Sorumlu Yazar, Araştırma Görevlisi, Ondokuz Mayıs Üniversitesi, Eğitim Fakültesi, Türkiye

Araştırma Görevlisi, Ondokuz Mayıs Üniversitesi, Eğitim Fakültesi, Türkiye

Doçent Doktor, Ondokuz Mayıs Üniversitesi, Eğitim Fakültesi, Türkiye 


\section{Introduction}

Although the concept outdoor education has begun to attract attention in the world especially in recent years, studies on the subject date back to very old times. The first time outdoor education is mentioned in formal education system dates back to 1920s (Smith, 1987). Therefore, it is not possible to say that outdoor education is a recently heard model in literature. Outdoor education is a process in which learning environment is carried beyond four walls, carried out in a planned, programmed, systematic way based on direct participation. In outdoor education the learning environment is chosen and shaped according to the subject to be taught. In this process, while students have a suitable environment to show the participation expected from them at the highest level, teachers also have the required means to carry out the process in a coordinated manner. In outdoor learning activities, the aim is to enable students to gain outdoor educational experiences in various environments; these experiences are aimed at providing students with a deep knowledge of environmental issues and improving students' self-confidence, environmental sensitivity, action skills and social relationships (Palmberg \& Kuru, 2000).

The concept of outdoor learning, which has a very broad conceptual framework and meaning in literature, can be thought as a model that includes every activity outside of school carried out for learning (Şimşek \& Kaymakçı, 2015). Outdoor learning refers to learning subjects in lessons directly in their own environment taking into account informal learning's characteristics of learning with free choice and in line with interests (Laçin-Şimşek, 2020). Outdoor learning, which is also called "education outside the classroom, indoor learning, nature education" (Ford, 1986) is an area on which different definitions are made. When the definitions on outdoor learning are evaluated together, in general it can be defined as an education process in which outdoor areas are used, which includes adventure, risks and danger, which focuses on individuals' social, physical, psychological and mental developments, which is based on experience, in which subjects of different disciplined can be discussed together, which can be stretched and adapted according to subject and content (Eaton, 2000; Bunting, 2006; Payne \& Wattchow, 2008; Becker, Lauterbach, Spengler, Dettweller \& Mess, 2017). Outdoor learning can also be described as a process which is based on application, which provides a connection between humans and the natural environment, which allows for individuals to gain more permanent and effective learning due to the experiences they gain by using one of their five senses in addition to being a process that requires permanence (Bunting, 2006). In this context, including outdoor learning in educational activities, integrating the curriculum with outdoor learning activities and providing these together to students is also important in terms of the quality of education processes. Outdoor learning attracts a lot of attention today. Within the context of 2023 Education Vision, the Ministry of National Education made attempts to associate places such as science centres, historical and cultural places, museums, art centres, natural sites, libraries, archaeological sites, universities, industrial establishments open to visitors with preschool, primary education, secondary education and teaching programs and to use these places as outdoor learning environment more effectively with the help of teacher guide books (Avc1 \& Gümüş, 2020). It is possible to see the effects of this intervention when teaching programs are examined. The emphasis in science course curriculum, Life Sciences lesson curriculum and Social Sciences lesson curriculum are significant indicators of the sensitivity felt for making use of outdoor environments in education and training processes in our country (MEB, 2018a; 2018b, 2018c);

In-class/school and outdoor learning environments are designed according to research-inquiry based learning strategy so that students can learn information meaningfully and permanently. In this context, informal learning environments (school garden, science centres, museums, planetariums, zoos, botanic gardens, natural environments, etc.),

Care should be taken to make in-school and outdoor practices while teaching the course. Especially in required acquisitions, outdoor practices such as verbal history, local history, museum visits, nature education, getting to know official institutions and organizations and private institutions and organizations should be taken into consideration and in this direction, pre-planned student centred activities should be carried out.

Care should be taken to make use of outdoor environments in Social Studies teaching. These studies may be carried out in the immediate surroundings of the school (like school garden), market place, 
offices, factories, exhibitions, archaeological excavation sites, workshops, museums and historical places (historical structures, monuments, museum-cities, battlefields, virtual museum visits, etc.). In addition, verbal history and local history studies should also be carried out on appropriate issues.

These emphases, which are the indicators of the importance given to outdoor learning by the Ministry of National Education, should evoke an idea beyond the thought that outdoor activities should take place only in courses. It is extremely important to comprehend the importance of outdoor activities as well as their meaning in order to complete course activities, to respond to students' diverse interests and needs and to provide a good citizenship education (Karademir, 2013).

While informal learning environments in which outdoor educational activities can be carried out are places such as aquariums, planetariums, museums, science centres; field trips, science camps and technical trips are also environments that can be used for outdoor learning (Ertaş, Şen \& Parmaksızoğlu, 2011). In general terms, outdoor learning includes all activities outside the four walls of the classroom and a school garden, a hospital in the environment, a park in the neighbourhood, museums, science centres and digital environments can be shown as examples to outdoor learning environments. Therefore, it is not possible to say that outdoor learning is completely different from formal learning; on the contrary, it is possible to say that education outside of school is another form of teaching the courses (Şen, 2019). The emergence of education outside of school and outdoor learning occurred due to the necessity of life-long learning and concrete, life-threatening and experiential activities emerged while students were looking for interesting things in their educational activities (Tösten, 2020). These activities, which can be carried out by carrying education outside of school, can be grouped in many different branches. Although people think of picnics and excursions for fun on the mention of outdoor activities, outdoor activities are now associated with courses and carried out within the scope of the subject and they refer to activities outside the school, courses or classroom (Karademir, 2013). With the help of outdoor learning activities which are planned visits carried out to complete activities in classroom and to make them more meaningful, students can recognize situations with their real appearance, learn information from their real source and make abstract element concrete (Çifçi \& Dikmenli, 2016). In addition to fostering pro-social behaviours, outdoor areas also create a natural environment to reduce bullying and teachers help their students to interact with each other (Burriss \& Burriss, 2011). Outdoor learning activities carried out in outdoor environments provide students with the opportunity to establish an experiential connection with the real world outside the classroom, to develop meaningful knowledge, skills and understanding, to provide opportunity for creative learning and thinking, and give them the chance to experience the way knowledge is used in practice (Korkmaz, 2020). According to Çifçi \& Dikmenli (2016) learning can be made more enjoyable and fun by associating nature, school and society through outdoor learning activities and these activities should be carried out in a planned and purposeful way according to the needs of students because thanks of these activities, students can gain skills such as design, analysis and synthesis and thus create new and different products by taking part in complicated missions (Çifçi \& Dikmenli, 2016). However, although the success achieved after outdoor learning activities is largely due to the teaching of these activities, the role of different factors in this success cannot be denied. The success of outdoor learning programs is also associated with students' previous experiences and social interactions (Sandell \& Öhman, 2013).

Many positive effects caused by outdoor learning on students give a good idea on the necessity that this model should be continued with students. However, at this point, maybe the most important detail is the perception levels of students who are directly related with the issue of outdoor learning. Although there are studies conducted with different education levels (Karakaya-Akçadağ \& Çobanoğlu, 2018; Çobanoğlu \& Cirit-Gül, 2017) and teachers (Sarışan-Tungaç \& Ünaldı-Coral, 2017) in the field of outdoor education in the literature, these studies are limited. Therefore, it is considered important to conduct this study to fill the gap in the literature. Therefore, answers were sought to the following sub-problems:

(1) Is there a significant difference between students' levels of perception of outdoor learning environments according to their gender?

(2) Is there a significant difference between students' levels of perception of outdoor learning environments according to their grades? 
(3) Is there a significant difference between students' levels of perception of outdoor learning environments according to their living places?

(4) Is there a significant difference between students' levels of perception of outdoor learning environments according to their holiday places?

\section{Method}

This study is a quantitative study conducted to find out the perception levels of secondary school students towards outdoor learning. The study was designed in accordance with survey model. Studies conducted with survey model try to find out the characteristics of a group such as attitudes, perceptions and skills in order to solve a problem related to a subject (Büyüköztürk, Kılıç-Çakmak, Akgün, Karadeniz \& Demirel, 2020).

\section{Participant Group}

The scale used in this study is suitable for secondary school students. For this reason, it was studied with secondary school students. The sample of the study consists of 980 secondary school students. Demografic data of 819 participants included in the data analysis after removing 161 outliers are presented below.

Table 1.

Demographic Data of the Participants

\begin{tabular}{cccccccccccc}
\hline \multicolumn{3}{c}{ Gender } & \multicolumn{3}{c}{ Grade } & Living Place & \multicolumn{2}{c}{ Holiday Areas } \\
\hline & Female & Male & 5.grade & $6 . g r a d e$ & 7. grade & 8.grade & City & Village & $\begin{array}{c}\text { Natural } \\
\text { Areas } \\
\text { (like a } \\
\text { village }\end{array}$ & $\begin{array}{c}\text { Unnatural } \\
\text { Areas (like } \\
\text { a city) }\end{array}$ \\
\hline Frequency & 461 & 358 & 224 & 158 & 221 & 216 & 598 & 221 & 717 & 102 \\
\hline Percent & 56.3 & 43.7 & 27.4 & 19.3 & 27.0 & 26.4 & 73.0 & 27.0 & 87.5 & 12.5 \\
\hline
\end{tabular}

According to Table 1, it can be seen that of the 819 participants, $461(56.3 \%)$ were female, while $358(43.7 \%)$ were male; $224(27.4 \%)$ were 5th graders, $158(19.3 \%)$ were 6th graders, 221 $(27.0 \%)$ were 7 th graders and $216(26.4 \%)$ were 8th graders; $598(73.0 \%)$ were living in city centres, $221(27.0 \%)$ were living in villages and $717(87.5 \%)$ were spending their holidays in natural areas, while $102(12.5 \%)$ were spending their holidays in unnatural areas.

\section{Data Collecting Process}

The research data were collected with Out of School Learning Environments Perception Scale (OSLEPS) developed by Şen, Ertaş-Kılıç, Oktay, Ekinci \& Kadirhan (2021). The items in the scale were transformed into an online form by using Google Forms and delivered to participants through online platforms. The participants who volunteered to participate in the study were asked to fill in the form. The scale is a 5-Likert type scale consisting of 4 factors (incentive for learning, learning benefits, integration, and involvement) and 16 items. The scale items were coded as 1 "Totally disagree", 2 "Disagree", 3 "Neutral", 4 "Agree" and 5 "Totally agree". The total alpha value of the scale is .80. Cronbach's alpha value is 0.68 for the first factor, 0.57 for the second factor, 0.60 for the third factor and 0.61 for the fourth factor. The KMO value of the scale is .841 .

\section{Data Analysis}

In the study, the participants were asked to answer some demographic questions in addition to scale items. Before analysis, normality tests were conducted to find out whether the data were normally distributed. As a result of the test, it was found according to Kolmogorov-Smirnov test that the data were not normally distributed $(\mathrm{p}=.000 ; \mathrm{p}<.05)$; however, since Skewness and Kurtosis values (Skewness=-.865, Kurtosis=-.008) were within normal limits, it was concluded that the data were normally distributed. However, when the table regarding outliers was examined, it was found that some of the values were outliers and these outliers which distorted the distribution were excluded from 
the data set. After the 161 outliers were excluded, while the data collected from 819 participants were not normally distributed according to the results of Kolmogorov-Smirnov test $(p=.000 ; p<.05)$, Skewness and Kurtosis values were within normal limits (Skewness=-.128, Kurtosis=-.082) and since no outliers were found, it was concluded that the data were normally distributed and the data were analyzed with parametric tests. In this part of the study, the scores of the participants from the factors of the scale and the overall scale were added up, their means were taken and the participants' means in incentive for learning, learning benefits, integration, and involvement factors and outdoor learning scores were found. The lowest score participants can get from the scale is 16 , while the highest score is 80 . Therefore, according to the total scores of the participants from the scale, the participants who got between 16 and 41.59 were considered to have low outdoor learning environment perceptions, while those who got between 41.6 and 54.39 were considered to have moderate perceptions and those who got between 54.4 and 80 were considered to have high perceptions. Similarly, since each factor has four items, the minimum possible score from each factor is 4 , while the maximum possible score is 20. The participants were evaluated in line with the scores they obtained from the scale in terms of the variables of gender, grade, where they lived and where they spent their holidays and the results were presented in tables. In data analysis, independent samples t-test and independent samples one way ANOVA techniques were used. Ethics committee permissions were obtained for the study.

\section{Results}

In this part of the study, total scores from the scales and perception levels of the participants regarding outdoor learning environments according to the variables were analyzed by using different analysis techniques and presented in tables.

\section{Results Regarding the Outdoor Learning Environments Perception Levels of the Participants in terms of Their Gender and Scores from the Scale}

In this part, the scores of the participants from the factors and overall scale were calculated in terms of their gender and their mean scores from incentive for learning, learning benefits, integration, and involvement factors and outdoor learning environments were presented in table with frequency and percentage.

Table 2.

Results regarding the outdoor learning environments perception levels of the participants in terms of their gender and scores from the scale

\begin{tabular}{cccccccc}
\hline Gender/Factor & \multicolumn{2}{c}{ Low } & \multicolumn{2}{c}{ Medium } & \multicolumn{2}{c}{ High } \\
\hline Incentive for learning & & Female & Male & Female & Male & Female & Male \\
& $\mathrm{f}$ & 16 & 22 & 87 & 82 & 358 & 254 \\
\cline { 2 - 8 } & $\%$ & 3.5 & 6.1 & 18.9 & 22.9 & 77.7 & 70.9 \\
\hline Learning benefits & $\mathrm{f}$ & 35 & 31 & 105 & 85 & 321 & 242 \\
\cline { 2 - 8 } & $\%$ & 7.6 & 8.7 & 22.8 & 23.7 & 69.6 & 67.6 \\
\hline Integration & $\mathrm{f}$ & 24 & 28 & 75 & 66 & 362 & 264 \\
\cline { 2 - 8 } & $\%$ & 5.2 & 7.8 & 16.3 & 18.4 & 78.5 & 73.7 \\
\hline Involvement & $\mathrm{f}$ & 35 & 39 & 112 & 85 & 314 & 234 \\
\hline Total & $\%$ & 7.6 & 10.9 & 24.3 & 23.7 & 68.1 & 65.4 \\
\hline & $\mathrm{f}$ & 16 & 14 & 92 & 94 & 353 & 250 \\
\hline & $\%$ & 3.5 & 3.9 & 20.0 & 26.3 & 76.6 & 69.8 \\
\hline
\end{tabular}

According to the data in Table 2, when the means of the participants in the study were examined in terms of the scores they got from the overall scale and from the factors, it was found that female students had higher mean scores in incentive for learning $\left(\overline{\boldsymbol{x}}_{\mathrm{female}}=96.6 \%>\overline{\boldsymbol{x}}_{\text {male }}=93.8 \%\right)$, learning benefits $\left(\overline{\boldsymbol{x}}_{\mathrm{female}}=92.4 \%>\overline{\boldsymbol{x}}_{\mathrm{male}}=91.3 \%\right)$, integration $\left(\overline{\boldsymbol{x}}_{\mathrm{female}}=94.8 \%>\overline{\boldsymbol{x}}_{\mathrm{male}}=92.1 \%\right)$, and involvement $\left(\overline{x_{\text {female }}}=92.4 \%>\overline{x_{\text {male }}}=89.1 \%\right)$ factors and outdoor learning environments $\left(\overline{\boldsymbol{x}}_{\mathrm{female}}=96.6 \%>\overline{\boldsymbol{x}_{\text {male }}}=96.1 \%\right)$ perception levels when compared with male students. 


\section{Results Regarding the Outdoor Learning Environments Perception Levels of the Participants in terms of Their Grade and Scores from the Scale}

In this part, the scores of the participants from the factors and overall scale were calculated in terms of their grade and their mean scores from incentive for learning, learning benefits, integration, and involvement factors and outdoor learning environments were presented in table with frequency and percentage.

Table 3.

Results regarding the outdoor learning environments perception levels of the participants in terms of their grade and scores from the scale

\begin{tabular}{|c|c|c|c|c|c|c|c|c|c|c|c|c|c|}
\hline \multirow[t]{2}{*}{ Grade/Factor } & & \multicolumn{4}{|c|}{ Low } & \multicolumn{4}{|c|}{ Medium } & \multicolumn{4}{|c|}{ High } \\
\hline & & $\begin{array}{c}5 . \\
\text { grade }\end{array}$ & $\begin{array}{l}6 . \\
\text { grade }\end{array}$ & $\begin{array}{c}7 . \\
\text { grade }\end{array}$ & $\begin{array}{c}8 . \\
\text { grade }\end{array}$ & $\begin{array}{c}5 . \\
\text { grade }\end{array}$ & $\begin{array}{l}6 . \\
\text { grade }\end{array}$ & $\begin{array}{c}7 . \\
\text { grade }\end{array}$ & $\begin{array}{c}8 . \\
\text { grade }\end{array}$ & $\begin{array}{c}5 . \\
\text { grade }\end{array}$ & $\begin{array}{c}6 . \\
\text { grade }\end{array}$ & $\begin{array}{c}7 . \\
\text { grade }\end{array}$ & $\begin{array}{c}8 . \\
\text { grade }\end{array}$ \\
\hline \multirow{2}{*}{$\begin{array}{c}\text { Incentive for } \\
\text { learning }\end{array}$} & $\mathrm{f}$ & 12 & 5 & 9 & 12 & 40 & 24 & 49 & 56 & 172 & 129 & 163 & 148 \\
\hline & $\%$ & 5.4 & 3.2 & 4.1 & 5.6 & 17.9 & 15.2 & 22.2 & 25.9 & 76.8 & 81.6 & 73.8 & 68.5 \\
\hline \multirow{2}{*}{$\begin{array}{l}\text { Learning } \\
\text { benefits }\end{array}$} & $\mathrm{f}$ & 20 & 9 & 16 & 21 & 49 & 39 & 56 & 46 & 155 & 110 & 149 & 149 \\
\hline & $\%$ & 8.9 & 5.7 & 7.2 & 9.7 & 21.9 & 24.7 & 25.3 & 21.3 & 69.2 & 69.6 & 67.4 & 69.0 \\
\hline \multirow[t]{2}{*}{ Integration } & $\mathrm{f}$ & 14 & 8 & 12 & 18 & 31 & 21 & 44 & 45 & 179 & 129 & 165 & 153 \\
\hline & $\%$ & 6.3 & 5.1 & 5.4 & 8.3 & 13.8 & 13.3 & 19.9 & 20.8 & 79.9 & 81.6 & 74.7 & 70.8 \\
\hline \multirow[t]{2}{*}{ Involvement } & $\mathrm{f}$ & 17 & 13 & 29 & 15 & 51 & 34 & 55 & 57 & 156 & 111 & 137 & 144 \\
\hline & $\%$ & 7.6 & 8.2 & 13.1 & 6.9 & 22.8 & 21.5 & 24.9 & 26.4 & 69.6 & 70.3 & 62.0 & 66.7 \\
\hline \multirow[t]{2}{*}{ Total } & $\mathrm{f}$ & 6 & 5 & 9 & 10 & 49 & 26 & 56 & 55 & 169 & 127 & 156 & 151 \\
\hline & $\%$ & 2.7 & 3.2 & 4.1 & 4.6 & 21.9 & 16.5 & 25.3 & 25.5 & 75.4 & 80.4 & 70.6 & 69.9 \\
\hline
\end{tabular}

When the data in Table 3 were examined, it was found that 6 th graders had higher mean scores in the first factor of the scale, incentive for learning $\left(\overline{\boldsymbol{x}}_{\text {6thgrade }}=96.8 \%>\overline{\boldsymbol{x}}_{7 \text { thgrade }}=96.0 \%>\overline{\boldsymbol{x}}_{\text {thgrade }}=94.7 \%>\overline{\boldsymbol{x}}_{\text {thgrade }}=94.4 \%\right)$, in the second factor of the scale, learning benefits $\left(\overline{\boldsymbol{x}}_{\text {thgrade }}=94.3 \%>\overline{\boldsymbol{x}}_{\text {thgrade }}=92.7 \%>\overline{\boldsymbol{x}}_{\text {thgrade }}=91.1 \%>\overline{\boldsymbol{x}}_{\text {8thgrade }}=90.3 \%\right)$ and third factor integration $\left(\overline{\boldsymbol{x}}_{\text {thgrade }}=94.9 \%>\overline{\boldsymbol{x}}_{\text {thgrade }}=94.6 \%>\overline{\boldsymbol{x}}_{\text {5thrade }}=93.7 \%>\overline{\boldsymbol{x}}_{\text {thgrade }}=91.6 \%\right)$ when compared with the students in other grades, while it was found that 8th graders had higher mean scores in the fourth factor of the scale, involvement $\left(\overline{\boldsymbol{x}}_{\text {thgrade }}=93.1 \%>\overline{\boldsymbol{x}}_{\text {thgrade }}=92.4 \%>\overline{\boldsymbol{x}}_{\text {thgrade }}=91.8 \%>\overline{\boldsymbol{x}}_{\text {thgrade }}=86.9 \%\right)$ and 5 th graders had high mean scores in the outdoor learning environments perception levels $\left(\overline{\boldsymbol{x}}_{\text {5thgrade }}=97.3 \%>\overline{\boldsymbol{x}}_{\text {thgrade }}=96.9 \%>\overline{\boldsymbol{x}}_{\text {thgrade }}=95.9 \%>\overline{\boldsymbol{x}}_{\text {8thgrade }}=95.4 \%\right)$ when compared with the other grades.

\section{Results Regarding the Outdoor Learning Environments Perception Levels of the Participants in terms of Where They Live and Their Scores from the Scale}

In this part, the scores of the participants from the factors and overall scale were calculated in terms of where they live and their mean scores from incentive for learning, learning benefits, integration, and involvement factors and outdoor learning environments were presented in table with frequency and percentage.

Table 4.

Results regarding the outdoor learning environments perception levels of the participants in terms of where they live and their scores from the scale

\begin{tabular}{cccccccc}
\hline Living Place/Factor & \multicolumn{3}{c}{ Low } & \multicolumn{2}{c}{ Medium } & \multicolumn{2}{c}{ High } \\
\hline & & City & Village & City & Village & City & Village \\
\hline Incentive for learning & $\mathrm{f}$ & 27 & 11 & 118 & 51 & 453 & 159 \\
\cline { 2 - 9 } & $\%$ & 4.5 & 5.0 & 19.7 & 23.1 & 75.8 & 71.9 \\
\hline Learning benefits & $\mathrm{f}$ & 42 & 24 & 140 & 50 & 416 & 147 \\
\cline { 2 - 8 } & $\%$ & 7.0 & 10.9 & 23.4 & 22.6 & 69.6 & 66.5 \\
\hline Integration & $\mathrm{f}$ & 39 & 13 & 97 & 44 & 462 & 164 \\
\hline & $\%$ & 6.5 & 5.9 & 16.2 & 19.9 & 77.3 & 74.2 \\
\hline Involvement & $\mathrm{f}$ & 58 & 16 & 141 & 56 & 399 & 149 \\
\hline & $\%$ & 9.7 & 7.2 & 23.6 & 25.3 & 66.7 & 67.4 \\
\hline
\end{tabular}


Table 4.

(continued)

\begin{tabular}{cccccccc}
\hline Living Place/Factor & & \multicolumn{2}{c}{ Low } & \multicolumn{2}{c}{ Medium } & \multicolumn{2}{c}{ High } \\
\hline \multirow{2}{*}{ Total } & & City & Village & City & Village & City & Village \\
\hline & $\mathrm{f}$ & 20 & 10 & 138 & 48 & 440 & 163 \\
\cline { 2 - 9 } & $\%$ & 3.3 & 4.5 & 23.1 & 21.7 & 73.6 & 73.8 \\
\hline
\end{tabular}

According to the data in Table 4, it was found that the participants who lived in cities had higher mean incentive for learning $\left(\overline{\boldsymbol{x}}_{\mathrm{city}}=95.5 \%>\overline{\boldsymbol{x}_{\text {village }}}=95.0 \%\right)$, learning benefits $\left(\overline{\boldsymbol{x}}_{\text {city }}=93.0 \%>\overline{\boldsymbol{x}}_{\text {village }}=89.9 \%\right)$ and outdoor learning environments $\left(\overline{\boldsymbol{x}}_{\text {city }}=96.7 \%>\overline{\boldsymbol{x}}_{\mathrm{village}}=95.5 \%\right)$ scores than those who lived in villages; while the participants who lived in villages had higher mean integration $\left(\overline{\boldsymbol{x}}_{\text {village }}=94.1 \%>\overline{\boldsymbol{x}}_{\text {city }}=93.5 \%\right)$ and involvement $\left(\overline{\boldsymbol{x}}_{\text {village }}=92.8 \%>\overline{\boldsymbol{x}}_{\text {city }}=90.3 \%\right)$ scores than those who lived in cities.

\section{Results Regarding the Outdoor Learning Environments Perception Levels of the Participants in terms of Where They Generally Spend Their Holiday and Their Scores from the Scale}

In this part, the scores of the participants from the factors and overall scale were calculated in terms of where they generally spend their holiday and their mean scores from incentive for learning, learning benefits, integration, and involvement factors and outdoor learning environments were presented in table with frequency and percentage.

Table 5 .

Results regarding the outdoor learning environments perception levels of the participants in terms of where they spend their holiday and their scores from the scale

\begin{tabular}{cccccccc}
\hline Holiday Place/Factor & \multicolumn{3}{c}{ Low } & \multicolumn{2}{c}{ Medium } & \multicolumn{2}{c}{ High } \\
\hline & & Natural & Unnatural & Natural & Unnatural & Natural & Unnatural \\
\hline Incentive for learning & $\mathrm{f}$ & 31 & 7 & 145 & 24 & 541 & 71 \\
\cline { 2 - 9 } & $\%$ & 4.3 & 6.9 & 20.2 & 23.5 & 75.5 & 69.6 \\
\hline Learning benefits & $\mathrm{f}$ & 57 & 9 & 163 & 27 & 497 & 66 \\
\cline { 2 - 8 } & $\%$ & 7.9 & 8.8 & 22.7 & 26.5 & 69.3 & 64.7 \\
\hline Integration & $\mathrm{f}$ & 44 & 8 & 121 & 20 & 552 & 74 \\
\cline { 2 - 8 } & $\%$ & 6.1 & 7.8 & 16.9 & 19.6 & 77.0 & 72.5 \\
\hline Involvement & $\mathrm{f}$ & 59 & 15 & 168 & 29 & 490 & 58 \\
\hline & $\%$ & 8.2 & 14.7 & 23.4 & 28.4 & 68.3 & 56.9 \\
\hline Total & $\mathrm{f}$ & 25 & 5 & 161 & 25 & 531 & 72 \\
\hline & $\%$ & 3.5 & 4.9 & 22.5 & 24.5 & 74.1 & 70.6 \\
\hline
\end{tabular}

As can be seen in the data in Table 5, when the participants' mean scores from all factors of the scale and the overall scale were compared, it was found that the participants who spent their holidays in natural places had higher mean scores in incentive for learning $\left(\overline{\boldsymbol{x}}_{\text {natural }}=95.7 \%>\overline{\boldsymbol{x}}_{\text {unnatural }}=93.1 \%\right)$, learning benefits $\left(\overline{\boldsymbol{x}}_{\text {natural }}=92.1 \%>\overline{\boldsymbol{x}_{\text {unnatural }}}=91.2 \%\right)$, integration $\left(\overline{\boldsymbol{x}}_{\text {natural }}=93.9 \%>\overline{\boldsymbol{x}_{\text {unnatural }}}=92.2 \%\right)$ and involvement $\left(\overline{\boldsymbol{x}_{\text {natural }}}=91.8 \%>\overline{\boldsymbol{x}_{\text {unnatural }}}=85.3 \%\right)$ factors and out-oflearning environments $\left(\overline{\boldsymbol{x}}_{\text {natural }}=96.5 \%>\overline{\boldsymbol{x}}_{\text {unnatural }}=95.1 \%\right)$ perception scores when compared with the participants who spent their holidays in unnatural places.

\section{Independent Samples t-test Results According to Participants' Genders and Outdoor Learning Environments Perception Levels}

In this part, the perception levels of the participants regarding the factors in the scale and outof-learning environments perception levels were compared according to their genders and the data obtained were shown below in table:

Table 6.

The data regarding Independent Samples $t$ test results conducted to compare outdoor learning environments perception levels of the participants according to their gender 


\begin{tabular}{|c|c|c|c|}
\hline Gender & & Female & Male \\
\hline $\mathrm{N}$ & & 461 & 358 \\
\hline \multirow{5}{*}{ Incentive for learning } & $\bar{x}$ & 15.503 & 14.961 \\
\hline & $S$ & 2.634 & 2.708 \\
\hline & $\mathrm{t}$ & 2.886 & \\
\hline & $\mathrm{Sd}$ & 817 & \\
\hline & $\mathrm{p}$ & .004 & \\
\hline \multirow{5}{*}{ Learning benefits } & $\bar{x}$ & 14.692 & 14.592 \\
\hline & $S$ & 2.798 & 2.776 \\
\hline & $\mathrm{t}$ & .509 & \\
\hline & $\mathrm{Sd}$ & 817 & \\
\hline & $\mathrm{p}$ & .611 & \\
\hline \multirow{5}{*}{ Integration } & $\bar{x}$ & 15.421 & 15.000 \\
\hline & $\mathrm{S}$ & 2.764 & 2.895 \\
\hline & $\mathrm{t}$ & 2.117 & \\
\hline & $\mathrm{Sd}$ & 817 & \\
\hline & $\mathrm{p}$ & .035 & \\
\hline \multirow{5}{*}{ Involvement } & $\bar{x}$ & 14.742 & 14.363 \\
\hline & $\mathrm{S}$ & 2.834 & 3.019 \\
\hline & $\mathrm{t}$ & 1.843 & \\
\hline & $\mathrm{Sd}$ & 817 & \\
\hline & $\mathrm{p}$ & .066 & \\
\hline \multirow{5}{*}{ Total } & $\bar{x}$ & 60.358 & 58.916 \\
\hline & $S$ & 9.227 & 9.205 \\
\hline & $\mathrm{t}$ & 2.220 & \\
\hline & $\mathrm{Sd}$ & 817 & \\
\hline & $\mathrm{p}$ & .027 & \\
\hline
\end{tabular}

As can be seen in data in Table 6, statistically significant difference was found between female and male students' incentive for learning $(\mathrm{p}=.004, \mathrm{p}<.05)$ and integration $(\mathrm{p}=.035, \mathrm{p}<.05)$ factors and their outdoor environments perception $(\mathrm{p}=.027, \mathrm{p}<.05)$ levels. When the results of this difference were examined, it was found that female students had higher incentive for learning $\left(\overline{\boldsymbol{x}_{\mathrm{female}}} 15.503>\overline{\boldsymbol{x}_{\mathrm{male}}}=14.961\right)$ and integration $\left(\overline{\boldsymbol{x}}_{\mathrm{female}}=15.421>\overline{\boldsymbol{x}_{\mathrm{male}}}=15.000\right)$ factors and outdoor learning environments perception $\left(\overline{\boldsymbol{x}_{\text {female }}}=60.358>\overline{\boldsymbol{x}_{\text {male }}}=58.916\right)$ levels than male students. No statistically significant difference was found between the groups in terms of learning benefits $(\mathrm{p}=.611$, $\mathrm{p}>.05)$ and involvement $(\mathrm{p}=.066, \mathrm{p}>.05)$ factors. It is thought that the reason for this may be the curiosity and interest of female students to nature and natural environments and their willingness to spend time in nature.

\section{Independent Samples One-way ANOVA Results According to Participants' Grades and Outdoor Learning Environments Perception Levels}

In this part, the perception levels of the participants regarding the factors in the scale and outdoor learning environments perception levels were compared according to their grades and the data obtained were shown below in table:

Table 7.

Independent Samples One-way ANOVA results conducted to compare outdoor learning environments perception levels of the participants according to their grades

\begin{tabular}{llccc}
\hline Feature & & Between Groups & Within Groups & Total \\
\hline \multirow{4}{*}{ Incentive for learning } & $\mathrm{KT}$ & 72.121 & 5799.852 & 5871.973 \\
\cline { 2 - 5 } & $\mathrm{sd}$ & 3 & 815 & 818 \\
\cline { 2 - 6 } & $\mathrm{KO}$ & 24.040 & 7.116 & \\
\cline { 2 - 6 } & $\mathrm{F}$ & 3.378 & & \\
\hline
\end{tabular}


Table 7.

(continued)

\begin{tabular}{|c|c|c|c|c|}
\hline Feature & & Between Groups & Within Groups & Total \\
\hline \multirow{2}{*}{ Incentive for learning } & $\mathrm{p}$ & .018 & & \\
\hline & $\eta 2$ & 0.012 & & \\
\hline \multirow{6}{*}{ Learning benefits } & KT & 19.458 & 6315.267 & 6334.725 \\
\hline & $\mathrm{sd}$ & 3 & 815 & 818 \\
\hline & $\mathrm{KO}$ & 6.486 & 7.749 & \\
\hline & $\mathrm{F}$ & .837 & & \\
\hline & $\mathrm{p}$ & .474 & & \\
\hline & $\eta 2$ & 0.003 & & \\
\hline \multirow{6}{*}{ Integration } & KT & 60.504 & 6481.542 & 6542.046 \\
\hline & $\mathrm{sd}$ & 3 & 815 & 818 \\
\hline & $\mathrm{KO}$ & 20.168 & 7.953 & \\
\hline & $\mathrm{F}$ & 2.536 & & \\
\hline & $\mathrm{p}$ & .056 & & \\
\hline & $\eta 2$ & 0.009 & & \\
\hline \multirow{6}{*}{ Involvement } & KT & 69.484 & 6908.496 & 6977.980 \\
\hline & $\mathrm{sd}$ & 3 & 815 & 818 \\
\hline & $\mathrm{KO}$ & 23.161 & 8.477 & \\
\hline & $\mathrm{F}$ & 2.732 & & \\
\hline & $p$ & .043 & & \\
\hline & $\eta 2$ & 0.010 & & \\
\hline \multirow{6}{*}{ Total } & KT & 737.577 & 69094.703 & 69832.281 \\
\hline & $\mathrm{sd}$ & 3 & 815 & 818 \\
\hline & $\mathrm{KO}$ & 245.859 & 84.779 & \\
\hline & $\mathrm{F}$ & 2.900 & & \\
\hline & $\mathrm{p}$ & .034 & & \\
\hline & $\eta 2$ & 0.011 & & \\
\hline
\end{tabular}

In Table 7, the participants' perception levels were determined according to their scores from the scale factors and the overall scale in terms of their gender. According to the table, while significant difference was found between groups in terms of incentive for learning $(\mathrm{p}=.018, \mathrm{p}<.05)$ and involvement $(\mathrm{p}=.043, \mathrm{p}<.05)$ factors and outdoor learning environments $(\mathrm{p}=.034, \mathrm{p}<.05)$ perception levels, no significant difference was found between groups in terms of learning benefits $(\mathrm{p}=.474$, $\mathrm{p}>.05)$ and integration $(\mathrm{p}=.056, \mathrm{p}>.05)$ factors. According to the results obtained, when post hoc analyses were conducted regarding the differences, it was found that 5th and 6th graders had higher incentive for learning levels when compared with 8th graders; although there was difference between involvement factor and outdoor learning environments perception levels, no difference was found to occur between the groups. It can be explained with the fact that younger age groups learn easier and more permanently in a concrete way, by touching, feeling, seeing.

\section{Independent Samples t-test Results According to Where the Participants Live and Their Outdoor Learning Environments Perception Levels}

In this part, the perception levels of the participants regarding the factors in the scale and outof-learning environments perception levels were compared according to where they live and the data obtained were shown below in table:

Table 8.

The data regarding Independent Samples $t$ test results conducted to compare outdoor learning environments perception levels of the participants according to where they live

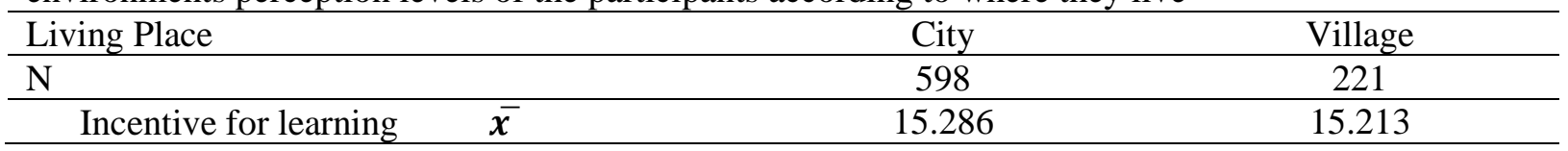


Table 8.

(continued)

\begin{tabular}{|c|c|c|c|}
\hline Living Place & & City & Village \\
\hline \multirow{4}{*}{ Incentive for learning } & S & 2.666 & 2.721 \\
\hline & $\mathrm{t}$ & .347 & \\
\hline & $\mathrm{Sd}$ & 817 & \\
\hline & $\mathrm{p}$ & .728 & \\
\hline \multirow{5}{*}{ Learning benefits } & $\bar{x}$ & 14.724 & 14.443 \\
\hline & $\mathrm{S}$ & 2.706 & 2.978 \\
\hline & $\mathrm{t}$ & 1.282 & \\
\hline & $\mathrm{Sd}$ & 817 & \\
\hline & $\mathrm{p}$ & .200 & \\
\hline \multirow{5}{*}{ Integration } & $\bar{x}$ & 15.252 & 15.195 \\
\hline & $\mathrm{S}$ & 2.862 & 2.741 \\
\hline & $\mathrm{t}$ & .260 & \\
\hline & $\mathrm{Sd}$ & 817 & \\
\hline & $\mathrm{p}$ & .795 & \\
\hline \multirow{5}{*}{ Involvement } & $\bar{x}$ & 14.587 & 14.548 \\
\hline & $S$ & 2.925 & 2.915 \\
\hline & $\mathrm{t}$ & .171 & \\
\hline & $\mathrm{Sd}$ & 817 & \\
\hline & $\mathrm{p}$ & .864 & \\
\hline \multirow{5}{*}{ Total } & $\bar{x}$ & 59.850 & 59.398 \\
\hline & $\mathrm{S}$ & 9.242 & 9.246 \\
\hline & $\mathrm{t}$ & .620 & \\
\hline & $\mathrm{Sd}$ & 817 & \\
\hline & $\mathrm{p}$ & .535 & \\
\hline
\end{tabular}

When the data in Table 8 were examined, it was found that there were no significant differences between incentive for learning $(p=.728, p>.05)$, learning benefits $(p=.200, p>.05)$, integration $(\mathrm{p}=.795, \mathrm{p}>.05)$ and involvement $(\mathrm{p}=.864, \mathrm{p}>.05)$ factors and out-of-learning environments perception $(p=.535, p>.05)$ levels of the groups in terms of where they lived. Since students living in city centres unfortunately lead their lives away from the nature and also lead a life full of technology, while it is expected for them to have lower perception levels than the students living in rural areas, the result that their perception levels were similar is a surprising result of the present study.

\section{Independent Samples t-test Results According to Where the Participants Generally Spent Their Holiday and Their Outdoor Learning Environments Perception Levels}

In this part, the perception levels of the participants regarding the factors in the scale and outdoor learning environments perception levels were compared according to where they spent their holiday and the data obtained were shown below in table:

Table 9.

The data regarding Independent Samples t test results conducted to compare outdoor environments perception levels of the participants according to where they spend their holidays

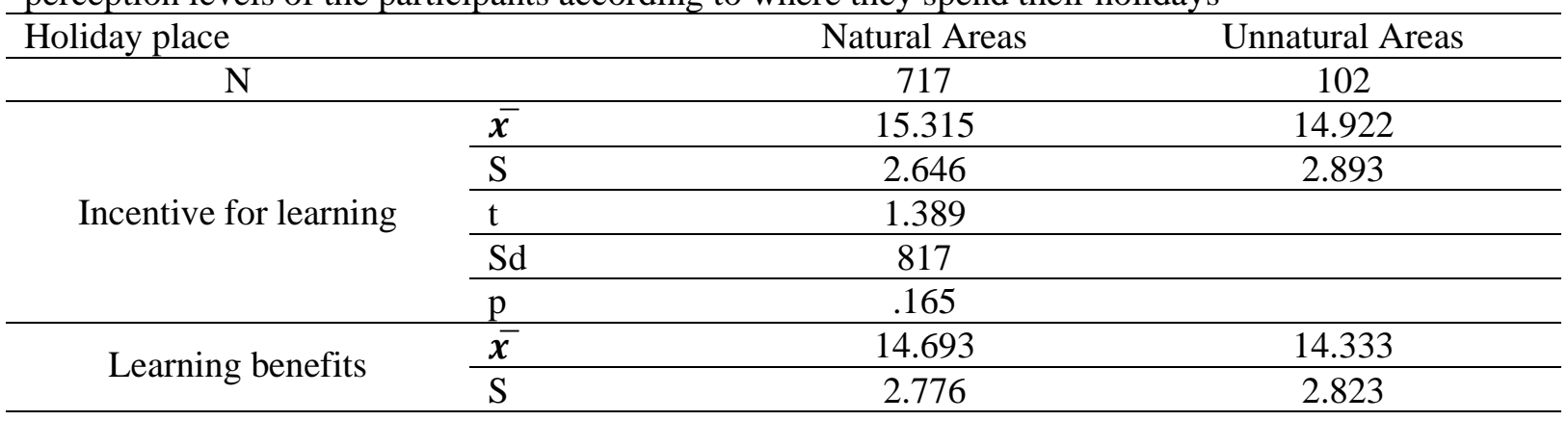


Table 9.

(continued)

\begin{tabular}{|c|c|c|c|}
\hline Holiday place & & Natural Areas & Unnatural Areas \\
\hline \multirow{3}{*}{ Learning benefits } & $\mathrm{t}$ & 1.222 & \\
\hline & $\mathrm{Sd}$ & 817 & \\
\hline & $p$ & .222 & \\
\hline \multirow{5}{*}{ Integration } & $\bar{x}$ & 15.272 & 14.990 \\
\hline & $\mathrm{S}$ & 2.818 & 2.903 \\
\hline & $\mathrm{t}$ & .941 & \\
\hline & $\mathrm{Sd}$ & 817 & \\
\hline & $p$ & .347 & \\
\hline \multirow{5}{*}{ Involvement } & $\bar{x}$ & 14.656 & 14.001 \\
\hline & $\mathrm{S}$ & 2.906 & 2.974 \\
\hline & $t$ & 2.098 & \\
\hline & $\mathrm{Sd}$ & 817 & \\
\hline & $\mathrm{p}$ & .036 & \\
\hline \multirow{5}{*}{ Total } & $\bar{x}$ & 59.937 & 58.254 \\
\hline & $\mathrm{S}$ & 9.210 & 9.359 \\
\hline & $\mathrm{t}$ & 1.723 & \\
\hline & $\mathrm{Sd}$ & 817 & \\
\hline & $p$ & .085 & \\
\hline
\end{tabular}

When the data in Table 9 are examined, it can be seen that there was significant difference between groups only in involvement $(p=.0036, p<.05)$ factor in terms of where the participants in the study spent their holiday. Regarding this difference, it was concluded that the students who spent their holidays in natural areas had higher perception levels than the students who spent their holidays in unnatural areas $\left(\overline{\boldsymbol{x}_{\text {natural }}}=14.656>\overline{\boldsymbol{x}_{\text {unnatural }}}=14.001\right)$. No significant difference was found between the groups in terms of incentive for learning $(\mathrm{p}=.165, \mathrm{p}>.05)$, learning benefits $(\mathrm{p}=.222, \mathrm{p}>.05)$ and integration $(\mathrm{p}=.347, \mathrm{p}>.05)$ factors and outdoor learning environments perception $(\mathrm{p}=.085, \mathrm{p}>.05)$ levels.

\section{Conclusion, Discussion and Recommendations}

In this study, which was conducted to determine the perceptions of students regarding outdoor learning environments, students' responses to OSLEPS were evaluated in terms of their gender, their grade, where they lived and where they spent their holidays. As a result of the analyses conducted, it was concluded that incentive for learning and integration factors of outdoor environments perceptions were high in both female and male students (Table 6), while they had more effect on female students when compared with male students and female students had higher outdoor environments scores. It is thought that the reason for this may be the curiosity and interest of female students to nature and natural environments and their willingness to spend time in nature. As stated in Avc1 \& Gümüş's (2019) study, this result of the study also explains high incentives of male students to learning as a result of learning through using different sense organs in outdoor environments and experiences. Neill (1997) stated that traditionally men were generally leaders in outdoor environments, but although men were still leaders in some areas, this situation had changed, while there were no differences between genders in terms of personal development. In this context, it can be said that the data obtained from this study are not in parallel with the results of studies in literature.

When outdoor environments perception levels were evaluated in terms of the students' grades (Table 7), the fact that students with lower grades had higher perception levels than students with higher grades can be explained with the fact that younger age groups learn easier and more permanently in a concrete way, by touching, feeling, seeing. The features of outdoor practices such as enabling students to visualize the subject, becoming more active by participating movement to this process and making it easier to learn new concepts by making them concrete (Bozdoğan \& Kavc1, 2016) explain the results of this study. In a study conducted in New Zealand, it was reported that while 
preparing curricula for younger age groups, the programs were designed in line with the physical and cognitive characteristics of that age group and that teaching practices in outdoor areas are included more (Zink \& Boyes, 2006). When this study and our study are evaluated together, it can be seen that the results found are in parallel. A surprising data in this study is the result that no significant difference was found between the outdoor learning environments of the students living in villages and those living in city centres. The fact that students living in villages are one with nature in their daily lives enables them to learn at higher levels by conducting their educational process outside of school. Since students living in city centres unfortunately lead their lives away from the nature and also lead a life full of technology, while it is expected for them to have lower perception levels than the students living in rural areas, the result that their perception levels were similar is a surprising result of the present study. In their study, Braun \& Dierkes (2017) concluded that students who spend more time in nature have higher connection with the nature. In another study by Avery and at. (2020), it was concluded that children who lived in rural areas had little or no fear of nature and the living beings in nature. It can be seen that this result of the study is not in parallel with the results of this study. When evaluated from this point of view, it can be considered as normal for this uncertainty caused by living away from nature to create an uncertainty and fear in children living in cities. Therefore, it can be explained why this study is surprising based on the data obtained from this study and the results of studies in literature.

Educational activities in open spaces are practices which appeal to all developmental areas of students and allow them to gain social skills and touch the soul, personality and character of students and minimize the differences between individuals. When evaluated in this context, it is important for such educational activities to be applied and integrated in educational programs especially in preschool and primary education where more concrete learning takes place. With such activities, especially students living in city centres can benefit from the healing power of nature. Since outdoor learning activities are activities in which five sense organs are used together, which include movement, excitement and curiosity and since they are educational processes which enable students to be continuously active within the process and increase their wish to learn and present information about different disciplines, it can be recommended to include such activities more in the education programs prepared. It can be recommended to include courses on how these educational processes can be carried out in environments outside of the classroom environment in undergraduate programs of prospective teachers in education faculties.

\section{Lisans Bilgileri}

e-Kafkas Eğitim Araştırmaları Dergisi'nde yayınlanan eserler Creative Commons Atıf-Gayri Ticari 4.0 Uluslararası Lisansı ile lisanslanmıştır.

\section{Copyrights}

The Works published in e-Kafkas Journal of Educational Research are licensed under a Creative Commons Attribution-NonCommercial 4.0 International License.

\section{Etik Beyannamesi}

$\mathrm{Bu}$ çalışmada "Yükseköğretim Kurumları Bilimsel Araştırma ve Yayın Etiği Yönergesi" kapsamında belirtilen kurallara uyulduğunu ve "Bilimsel Araştırma ve Yayın Etiğine Aykırı Eylemler" başlığı altında belirtilen eylemlerden hiçbirini gerçekleştirmediğimizi beyan ederiz. Aynı zamanda yazarlar arasında çıkar çatışmasının olmadığını, tüm yazarların çalışmaya katkı sağladığını ve her türlü etik ihlalinde sorumluluğun makale yazarlarına ait olduğunu bildiririz.

\section{Etik Kurul İzin Bilgileri}

Etik kurul adı: Ondokuz Mayıs Üniversitesi Sosyal ve Beşeri Bilimler Etik Kurulu

Etik kurul karar tarihi: 26.02.2021

Etik kurul belgesi sayı numarası: 2021/196 


\section{References}

Avc1, G. \& Gümüş, N. (2019). Sınıf dış1 eğitim etkinliklerine yönelik öğrenci görüşleri. Turkish Studies, Educational Sciences, 3, 351-377. Retrieved from http://hdl.handle.net/11772/2580

Avc1, G. \& Gümüş, N. (2020). 2023 eğitim vizyonu ve okul dişı eğitim. Oral presentation presented at the II. International Ankara Conference of Scientific Research, Ankara, Turkey. Retrieved from https://www.kongreuzmani.com/site.html?https://www.ankarakongresi.org

Avery, E. E., Baumer, M. D., Hermsen, J. M., Leap, B. T., Lucht, J. R., Rikoon, J. S. \& WilhelmStanis, S. A. (2020). Measuring place of residence across urban and rural spaces: An application to fears associated with outdoor recreation. The Social Science Journal, 1-13. doi:10.1016/j.soscij.2019.08.007

Becker, C., Lauterbach, G., Spengler, S., Dettweiler, U. \& Mess, F. (2017). Effects of regular classes in outdoor education settings: A systematic review on students' learning, social and health dimensions. International Journal of Environmental Research and Public Health, 5, 485. doi:10.3390/ijerph14050485

Bozdoğan, A. E. \& Kavc1, A. (2016). Sınıf dışı öğretim etkinliklerinin ortaokul öğrencilerinin fen bilimleri dersindeki akademik başarılarına etkisi. Gazi Eğitim Bilimleri Dergisi, 2(1), 13-30.

Braun, T. \& Dierkes, P. (2017). Connecting students to nature-how intensity of nature experience and student age influence the success of outdoor education programs. Environmental Education Research, 7, 937-949. doi:10.1080/13504622.2016.1214866

Bunting, C. J. (2006). Interdisciplinary Teaching Through Outdoor Education. Human Kinetics.

Burriss, K. G. \& Burriss, L. (2011). Outdoor play and learning: Policy and practice. International Journal of Education Policy and Leadership, 6(8), 1-12.

Büyüköztürk, Ş., Kılıç-Çakmak, E., Akgün, Ö. E., Karadeniz, Ş. \& Demirel, F. (2020). Bilimsel Araştırma Yöntemleri. Ankara: Pegem Akademi.

Çifçi, T. \& Dikmenli, Y. (2016). Coğrafya öğretmenlerinin okul dışı coğrafya öğretimine ilişkin görüşleri. Ahi Evran Üniversitesi Kırşehir Eğitim Fakültesi Dergisi, 17(1), 363-382.

Çobanoğlu, E. O. \& Cirit-Gül, A. (2017). İlkokul 4. Sınıf müfredatında yer alan cümlenin öğeleri konusunun sınıf dışı (outdoor) etkinliklerle desteklenerek öğretilmesi. Uluslararası Türk Eğitim Bilimleri Dergisi, 5(9), 521-531.

Eaton, D. (2000). Cognitive and affective learning in outdoor education. (Unpublished doctoral dissertation). University of Toronto, Canada.

Ertaş, H., Şen, A. İ. \& Parmaksızoğlu, A. (2011). Okul dışı bilimsel etkinliklerin 9. Sınıf öğrencilerinin enerji konusunu günlük hayatla ilişkilendirme düzeyine etkisi. Necatibey Ĕgitim Fakültesi Elektronik Fen ve Matematik Eğitimi Dergisi, 5(2), 178-198. Retrieved from https://dergipark.org.tr/en/pub/balikesirnef/issue/3373/46558

Ford, P. (1986). Outdoor Education: Definition and Philosophy. New Mexico: ERIC Clearinghouse on Rural Education and Small Schools.

Karademir, E. (2013). Öğretmen ve öğretmen adaylarının fen ve teknoloji dersi kapsamında "okul dışı ögrrenme etkinliklerini" gerçekleştirme amaçlarının planlanmış davranış teorisi yoluyla belirlenmesi. (Unpublished doctoral dissertation). Hacettepe Üniversitesi, Ankara.

Karakaya-Akçadağ, Ç. \& Çobanoğlu, E. O. (2018). "İnsan ve çevre” ünitesi için sınıf dış1 öğretim uygulamasının çevre okuryazarlığı üzerine etkisi. İnformal Ortamlarda Araştırmalar Dergisi, $3(2), 1-23$.

Korkmaz, Z. S. (2020). Kuramdan uygulamaya okul dışı öğrenme ortamları. A. Küçükoğlu and H. İ. Kaya (Eds.), in the Okul dişı ortamlarda ögretim (pp. 23-54). Ankara: Pegem Akademi.

Laçin-Şimşek, C. (2020). Fen öğretiminde okul dışı öğrenme ortamları. C. Laçin-Şimşek (Ed.), in the Giriş (Okul dışı ögrenme) (pp. 1-18). Ankara: Pegem Akademi.

MEB, (2018a). Fen Bilimleri Dersi Öğretim Programı (İlkokul ve Ortaokul 3, 4, 5, 6, 7 ve 8. sınıflar), Ankara.

MEB, (2018b). Hayat Bilgisi Dersi Öğretim Programı (İlkokul 1, 2 ve 3. sınıflar), Ankara.

MEB, (2018c). Sosyal Bilgiler Dersi Öğretim Programı (İlkokul ve Ortaokul 4, 5, 6 ve 7. sinıflar), Ankara.

Neill, J. T. (1997, January). Gender: How does it effect the outdoor education experience. In Catalysts for change: 10th National Outdoor Education conference proceedings (pp. 1-9). Sydney, Australia. 
Palmberg, I. E. \& Kuru, J. (2000) Outdoor activities as a basis for environmental responsibility, The Journal of Environmental Education, 4, 32-36. doi:10.1080/00958960009598649

Payne, P. G. \& Wattchow, B. (2008). Slow pedagogy and placing education in post-traditional outdoor education. Journal of Outdoor and Environmental Education, 12(1), 25-38. doi:10.1007/BF03401021

Sandell, K. \& Öhman, J. (2013) An educational tool for outdoor education and environmental concern, Journal of Adventure Education \& Outdoor Learning, 1, 36-55. doi:10.1080/14729679.2012.675146

Sarışan-Tungaç, A. \& Ünald1-Coral M. N. (2017). Fen bilimleri öğretmenlerinin okul dışı (doğa deneyimine dayalı) eğitime yönelik görüşlerinin değerlendirilmesi. International Journal of Eurasia Social Sciences, 8(26), 24-42.

Smith, P. R. (1987). Outdoor education and its educational objectives. Geography, 72(3), 209-216.

Şen, A. İ. (2019). Okul dışı öğrenme ortamları. A. İ. Şen (Ed.), in the Okul dışı öğrenme nedir? (pp. 120). Ankara: Pegem Akademi.

Şen, A. İ., Ertaş-Kılıç, H., Oktay, Ö., Ekinci, S. \& Kadirhan, Z. (2021). Learning science outside the classroom: Development and validation of the out-of-school learning environments perception scale. Journal of Outdoor and Environmental Education, 24, 19-36. doi: 10.1007/s42322-02000070-7

Şimşek, A. \& Kaymakçı, S. (2015). Okul dışı Sosyal Bilgiler öğretimi, Ankara: Pegem Akademi.

Tösten, R. (2020). Kuramdan uygulamaya okul dış1 öğrenme ortamları. A. Küçükoğlu and H. İ. Kaya (Eds.), in the Okul dlşı eğitim ve ögrenme (pp. 1-22). Ankara: Pegem Akademi.

Zink, R. \& Boyes, M. (2006). The nature and scope of outdoor education in New Zealand schools. Journal of Outdoor and Environmental Education, 10(1), 11-21. doi:10.1007/BF03400826 